\title{
A Simple and Specific Colorimetric Determination of Cysteine with $p$-Dimethylaminocinnamaldehyde
}

\author{
By Shinji Ohmori, Mikiko Ikeda, Hiroko Hattori, Keiko Hagiwara and Chiemi Iwase \\ Faculty of Pharmaceutical Sciences, Okayama University, Okayama 700, Japan
}

(Received April 28/August 29. 1983)

\begin{abstract}
Summary: A simple and specific assay was developed for the determination of cysteine. Cysteine was reacted with $p$-dimethylaminocinnamaldehyde in methanol at $60^{\circ} \mathrm{C}$ for $2 \mathrm{~h}$ in the presence of sulphuric acid as a catalyst. Absorbance was measured at $587 \mathrm{~nm}$; the chromogen was stable at $60^{\circ} \mathrm{C}$ for at least $5 \mathrm{~h}$. The colour reaction was specific for cysteine, and was negative for other amino acids but positive for cysteamine. The absorbance followed Beer's law in the range from 0.825 to $413 . \mu \mathrm{mol} / \mathrm{l}$, and the apparent molar lineic absorbance was calculated to be $5000 \mathrm{~m}^{2} \cdot \mathrm{mol}^{-1}$. This procedure is applicable to the determination of cysteine and cystine in amino acid mixtures and in plasma, since cystine can be quantitatively reduced to cysteine with dithiothreitol under alkaline conditions. Recovery of cysteine and cystine from human plasma was 98.5 to $103 \%$ and 94.2 to $102 \%$, respectively.
\end{abstract}

\section{Einfache und spezifische kolorimetrische Bestimmung von Cystein mit p-Dimethylaminocinnamaldehyd}

Zusammenfassung: Eine einfache und spezifische Methode zur Bestimmung von Cystein wurde entwickelt. Cystein wurde mit $p$-Dimethylaminocinnamaldehyd und Schwefelsäure als Katalysator in Methanol bei $60^{\circ} \mathrm{C}$ für $2 \mathrm{~h}$ zur Reaktion gebracht. Die Absorption wurde dann bei $587 \mathrm{~nm}$ getestet. Das Chromogen war bei $60^{\circ} \mathrm{C}$ für mindestens $5 \mathrm{~h}$ stabil. Die Farbreaktion war spezifisch für Cystein und negativ für andere Aminosäuren, jedoch positiv für Cysteamin. Die Absorption folgte dem Beer'schen Gesetz im Bereich von 0,825 bis $413 \mu \mathrm{mol} / \mathrm{l}$ Cystein und die Berechnung der molaren linearen Absorbanz ergab $5000 \mathrm{~m}^{2} \cdot \mathrm{mol}^{-1}$. Das Verfahren ist auf die Bestimmung von Cystein und Cystin in Aminosäure-Gemischen und Plasma anwendbar, weil Cystin zu Cystein mit Dithiothreitol unter basischen Bedingungen quantitativ reduziert wurde. Cystein wurde aus menschlichem Plasma im Bereich von 98,5 bis $103 \%$ und Cystin von 94,2 bis $102 \%$ wiedergefunden.

\section{Introduction}

Many methods for the determination of cysteine and cystine have been reported. These methods depend on ion-exchance chromatography $(1-4)$, spectrophotometry (5-7), gas chromatography (8), thị layer chromatography (9), polarography (10), fluorometry (11), enzymatic reaction (12) and high performance liquid chromatography $(13-15)$, which has been the subject of many recent publications. High performance liquid chromatography analysis is too elaborate and time consuming. The method of
Gaitonde (5), which is based on coloration of cysteine with the modified ninhydrin reagent, is widely used because of its simplicity and specificity.

In the present paper, we describe a new method for the determination of cysteine, based on the formation of a chromophore with $p$-dimethylaminocinnamaldehyde; it is applicable to amino acid mixtures and plasma. The quantification of cystine, after reduction to cysteine with dithiothreitol under alkaline conditions, is also presented. 


\section{Materials and Methods}

\section{Reagents and Instruments}

GSH and GSSG were kindly supplied by Yamanouchi Pharmaceutical Co. Ltd. (Tokyo). L-Cystathionine was isolated and purified from the urine of a cystathionuric patient by Mizuhara and his coworkers at this university. $L$-Homocysteine and $L$-homocystine were prepared in this laboratory according to the method described in I.c. (16). N-Acetylcysteine, S-methylcysteine, L-cysteamine, cysteine methyl ester, cysteic acid, taurine, $p$-dimethylaminocinnamaldehyde and all other reagents of analytical grade were purchased from Wako Pure Chemicals Ind. Ltd. (Osaka).

A Shimadzu UV-180 spectrophotometer equipped with a recorder was used for measuring the absorbance at $587 \mathrm{~nm}$ and for recurding the absorption spectra. Evaporation of organic solvents and water under reduced pressure was carried out with a Speed Vac Concentrator (Savant. USA), unless otherwise stated. This apparatus permits the simultaneous treatment of 24 samples. The analysis of cysteine by high performance liquid chromatography was carried out with a Shimadzu model LC-3A system.

\section{Methods}

Fundamental to this method is the dual function of dithiothreitol; it serves as the SH-protecting agent in acidic solution and as the reducing agent in alkaline solution.

Colorimetric determination of cysteine in an aqueous solution and in amino acid mixtures

A sample solution $(0.5 \mathrm{ml})$ was added to $2 \mathrm{~mol} / \mathrm{l} \mathrm{HCl}(50 \mu \mathrm{l}), 0.01$ $\mathrm{mol} / / \mathrm{EDTA}(50 \mu \mathrm{l})$ and $10 \mathrm{~g} / \mathrm{l}$ dithiothreitol $(50 \mu \mathrm{l})$. After evaporation under reduced pressure, $1.0 \mathrm{ml}$ of $3 \mathrm{~g} / \mathrm{l} p$-dimethylaminocinnamaldehyde solution in methanol and $1.0 \mathrm{ml}$ of $2 \mathrm{~g} / \mathrm{sulphuric}$ acid solution in methanol were added to the dried residue. After thorough mixing, the solution was kept in a water bath at $60^{\circ} \mathrm{C}$ for $2 \mathrm{~h}$ in a tightly capped $3 \mathrm{ml}$ specimen vial (Iwaki Glass Co. Ltd., Tokyo). The absorbance was then measured at $587 \mathrm{~nm}$ against a blank containing $p$-dimethylaminocinnamaldehyde and sulphuric acid.

\section{Colorimetric determination of cystine in an aqueous solution}

Cystine was reduced to cysteine with dithiothreitol under alkaline conditions. A sample solution $(0.5 \mathrm{ml})$ was made alkaline by addition of $50 \mathrm{~g} / 1 \mathrm{NaHCO}_{3}(0.1 \mathrm{ml})$, to which $10 \mathrm{~g} / \mathrm{l}$ dithiothreitol $(50 \mu \mathrm{l})$ was added. After incubation at $37^{\circ} \mathrm{C}$ for $30 \mathrm{~min}$, the reaction mixture was acidified with $2 \mathrm{~mol} / \mathrm{l} \mathrm{HCl}(50 \mu \mathrm{l})$, and $0.01 \mathrm{~mol}-$ $\Lambda$ EDTA $(50 \mu \mathrm{l})$ was then added. After evaporation under reduced pressure, the dried residue was treated in the same manner as described above.

Individual colorimetric determination of cysteine and cystine in an aqueous solution

A sample solution was divided into two portions. Cysteine was determined as described above, and total cysteine (cysteine and cystine) after reduction of cystine with dithiothreitol in the above procedure. The difference between both values divided by 2 represented the cystine concentration.

\section{Colorimetric determination of cysteine in plasma}

Plasma $(0.8 \mathrm{ml})$ was divided into two portions. A $0.4 \mathrm{ml}$ aliquot was added to a mixture containing $50 \mu \mathrm{l}$ of $2 \mathrm{~mol} / / \mathrm{HCl}, 50 \mu \mathrm{l}$ of $10 \mathrm{~g} / \mathrm{l}$ dithiothreitol. $50 \mu \mathrm{l}$ of $0.01 \mathrm{~mol} / / \mathrm{EDTA}$ and $3 \mathrm{ml}$ of chloroform-ethanol $(2+1$, by volume). After stirring with a Vortex- mixer, the mixture was centrifuged at $1000 \mathrm{~g}$ for $15 \mathrm{~min}$. The supernatant was transferred to a $3 \mathrm{ml}$ vial, and evaporated to dryness under reduced pressure.

The remaining $0.4 \mathrm{ml}$ aliquot was added to chloroform-ethanol $(3 \mathrm{ml})$, followed by stirring and centrifugation as described above. After reaction of the supernatant with $25 \mathrm{~g} / \mathrm{N}$-ethylmaleimide $(0.1 \mathrm{ml})$ at room temperature for $20 \mathrm{~min}$ to eliminate intrinsic cysteine, the reaction mixture was added to ar mixture containing $50 \mu \mathrm{l}$ of $2 \mathrm{~mol} / \mathrm{HCl}, 50 \mu \mathrm{l}$ of $10 \mathrm{~g} / \mathrm{d}$ dithiothreitol and $50 \mu \mathrm{l}$ of $0.01 \mathrm{~mol} / / \mathrm{EDTA}$; this was evaporated to dryness under reduced pressure, and used as a blank after colour development.

Both dried residues were treated in the same manner as described for cysteine in aqueous solution, except that $1.0 \mathrm{ml}$ of a solution containing $6 \mathrm{~g} / 1$ (instead of $3 \mathrm{~g} / 1$ ) p-dimethylaminocinnamaldehyde solution was added to them. The cysteine concentration was estimated from the difference between both absorbances.

\section{Colorimetric determination of cystine and total cysteine in plasma}

Plasma (1.2 ml) was divided into three portions: sample A for cystine determination, sample $\mathrm{B}$ for total cysteine determination and sample $C$ as a blank for both determinations.

Each $0.4 \mathrm{ml}$ aliquot was deproteinized with $3 \mathrm{ml}$ of chloroformethanol as described in the previous section. Sample $A$ and $C$ were reacted with $25 \mathrm{~g} / \mathrm{l} \mathrm{N}$-ethylmaleimide $(0.1 \mathrm{ml})$ at room temperature for $20 \mathrm{~min}$, while water $(0.1 \mathrm{ml})$ was added to sample $\mathrm{B}$. The sample $C$ was added to a mixture of $0.1 \mathrm{ml}$ of $50 \mathrm{~g} / 1 \mathrm{NaHCO}_{3}$, $50 \mu \mathrm{l}$ of $2 \mathrm{~mol} / \mathrm{H} \mathrm{HCl}$ and $50 \mu \mathrm{l}$ of $0.01 \mathrm{~mol} / \mathrm{l}$ EDTA, then evaporated to dryness under reduced pressure. Sample $A$ and $B$ were added to $50 \mathrm{~g} / 1 \mathrm{NaHCO}_{3}(0.1 \mathrm{ml})$ and $35 \mathrm{~g} / \mathrm{l}$ dithiothreitol $(50 \mu \mathrm{l})$, followed by incubation at $37^{\circ} \mathrm{C}$ for $30 \mathrm{~min}$. After addition of $50 \mu \mathrm{l}$ of $2 \mathrm{~mol} / / \mathrm{HCl}$ and $50 \mu \mathrm{l}$ of $0.01 \mathrm{~mol} / \mathrm{EDTT}$ to both reaction mixtures, they were evaporated to dryness under reduced prèssure. The dried residues were treated in the same manner as described in the previous section. The cystine concentration was estimated from the difference between the absorbances of the sample $A$ and $C$, and total cysteine from the absorption difference of samples $B$ and $C$. Needless to say, the cysteine concentration could be also estimated from the difference between total cysteine and cystine.

Determination of cysteine, cystine and total cysteine in plasma by the modified method of Gaitonde

In order to confirm the reliability of the data obtained by the present method, the method of Gaitonde was modified for the pretreatment of samples as follows.

Plasma $(2.0 \mathrm{ml})$ was deproteinized with $700 \mathrm{~g} / \mathrm{kg} \mathrm{HClO}_{4}(0.2 \mathrm{ml})$, followed by centrifugation at $7000 \mathrm{~g}$ for $4 \mathrm{~min}$. The supernatant was adjusted to $2.0 \mathrm{ml}$ with deionized water. A $0.5 \mathrm{ml}$ aliquot for cysteine determination (sample D) was added to $100 \mathrm{~g} / 1 \mathrm{Na}_{2} \mathrm{CO}_{3}$ $(0.4 \mathrm{ml})$, water $(0.1 \mathrm{ml})$, glacial acetic acid $(0.5 \mathrm{ml})$ and the acid ninhydrin reagent 2 (see l.c. (5)) $(0.5 \mathrm{ml}$ ), followed by stirring and heating at $100^{\circ} \mathrm{C}$ for $10 \mathrm{~min}$ in a water bath. After cooling, ethanol $(2.0 \mathrm{ml})$ was added to the reaction mixture, and the absorbañce was measured at $560 \mathrm{~nm}$ against a reagent blank. The second $0.5 \mathrm{ml}$ aliquot for total cysteine determination (sample E) was added to $100 \mathrm{~g} / 1 \mathrm{Na}_{2} \mathrm{CO}_{3}(0.4 \mathrm{ml})$ and $10 \mathrm{~g} / \mathrm{l}$ dithiothreitol $(50$ $\mu \mathrm{l})$, followed by incubation at $37^{\circ} \mathrm{C}$ for $30 \mathrm{~min}$, and the colour was developed as described above. The third $0.5 \mathrm{ml}$ aliquot (sample F) served as a blank for the determination of cysteine and total cysteine; this was added to $100 \mathrm{~g} / 1 \mathrm{Na}_{2} \mathrm{CO}_{3}(0.4 \mathrm{ml})$ and $25 \mathrm{~g} / \mathrm{N} \mathrm{N}$ ethylmaleimide $(0.1 \mathrm{ml})$, followed by incubation at room temperature for $20 \mathrm{~min}$, and the colour was developed as described above.

The cysteine concentration was estimated from the difference between the absorbances of samples $D$ and $\vec{F}$, and total cysteine from the absorption difference of samples $E$ and $F$. Cystine was calculated from the difference between totalycysteine and cystine. 
Determination of cysteine and total cysteine in plasma by high performance liquid chromatography

In order to confirm the reliability of the data obtained by the present method, a high performance liquid chromatographic method was devised and carried out as follows.

Plasma $(1.0 \mathrm{ml})$ was deproteinized with $0.1 \mathrm{ml}$ of $500 \mathrm{~g} / \mathrm{kg}$ trichloroacetic acid, followed by centrifugation as described above. The supernatant was adjusted to $1.0 \mathrm{ml}$ with deionized water. A $0.25 \mathrm{ml}$ aliquot for cysteine determination was added to $100 \mathrm{~g} / \mathrm{A}$ $\mathrm{Na}_{2} \mathrm{CO}_{3}(0.2 \mathrm{ml})$, water $(0.1 \mathrm{ml})$ and $0.5 \mathrm{~mol} /$ iodoacetic acid $(50 \mu \mathrm{l})$, followed by incubation at room temperature for $20 \mathrm{~min}$. Another $0.25 \mathrm{ml}$ aliquot for total cysteine determination was added to $100 \mathrm{~g} / 1 \mathrm{Na}_{2} \mathrm{CO}_{3}(0.2 \mathrm{ml})$ and $10 \mathrm{~g} / 1$ dithiothreitol $(0.1 \mathrm{ml})$, followed by incubation at $37^{\circ} \mathrm{C}$ for $30 \mathrm{~min}$. To the reaction mixture $0.5 \mathrm{~mol} / \mathrm{h}$ iodoacetic acid $(50 \mu \mathrm{l})$ was added, and the mixture was allowed to stand at room temperature for $20 \mathrm{~min}$. To both reaction mixtures $(0.6 \mathrm{ml}) 10 \mu \mathrm{l}$ of 2,4-dinitrofluorobenzene was added, followed by incubation at $30^{\circ} \mathrm{C}$ for $1 \mathrm{~h}$ with vigorous shaking. The mixture was acidified with $6 \mathrm{moV} / \mathrm{HCl}(50 \mu \mathrm{l})$, followed by the addition of benzene $(1 \mathrm{ml})$. After vigorous stirring, the mixture was centrifuged at $7000 \mathrm{~g}$ for $4 \mathrm{~min}$. After removal of the organic layer by aspiration, an aliquot $(5-25 \mu$ for total cysteine determination and $50-100 \mu l$ for cysteine determination) of the aqueous phase was subjected to high performance liquid chromatography.

The analytical conditions were as follows. The column, $150 \times$ $4.6 \mathrm{~mm}$ i.d., packed with octadecylsilane bonded to microparticula (Zorbax ODS, Du Pont Co., USA) was used. The flow rate was $1.0 \mathrm{ml} / \mathrm{min}$, and the column temperature was maintained at $44^{\circ} \mathrm{C}$. The mobile phase was isocratic. $0.01 \mathrm{~mol} / \mathrm{l}$ acetate buffer $(\mathrm{pH}$ 3.65 ) - acetonitrile $(96+4$, by volume); this was allowed to flow for $20 \mathrm{~min}$, then changed to $700 \mathrm{ml} / 1$ methanol for $10 \mathrm{~min}$. The detection was carried out at $375 \mathrm{~nm}$. Peak height was used for the quantification. A good linearity was obtained in the range from 2 to $100 \mu \mathrm{mol} / \mathrm{l}$ reaction mixture, and typical chromatograms are shown in figure 1.

\section{Results}

\section{Absorption spectrum}

The absorption spectrum of the coloured solution obtained from cysteine is shown in figure 2 . The absorption maxima of cysteine are observed at 480 and $587 \mathrm{~nm}$. Amino acids other than cysteine developed colour with weak absorbance in the range from 470 to $490 \mathrm{~nm}$ (data not shown). The wavelength of $587 \mathrm{~nm}$ was chosen for the quantification because of its specificity for cysteine.

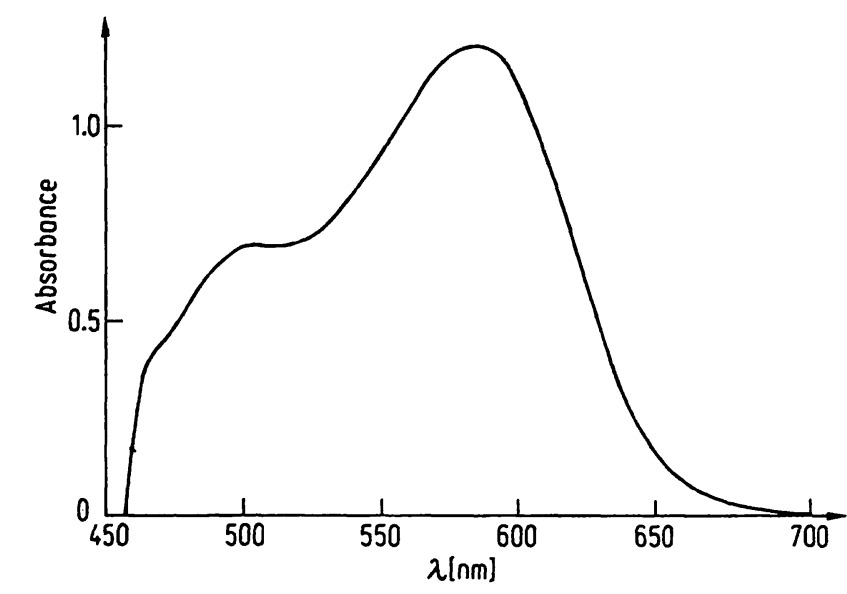

Fig. 2. Absorption spectrum of the coloured solution from cysteine. Cysteine $(41.3 \mathrm{nmol})$ was reacted with $p$-dimethylaminocinnamaldehyde and sulphuric acid in methanol under standard conditions.
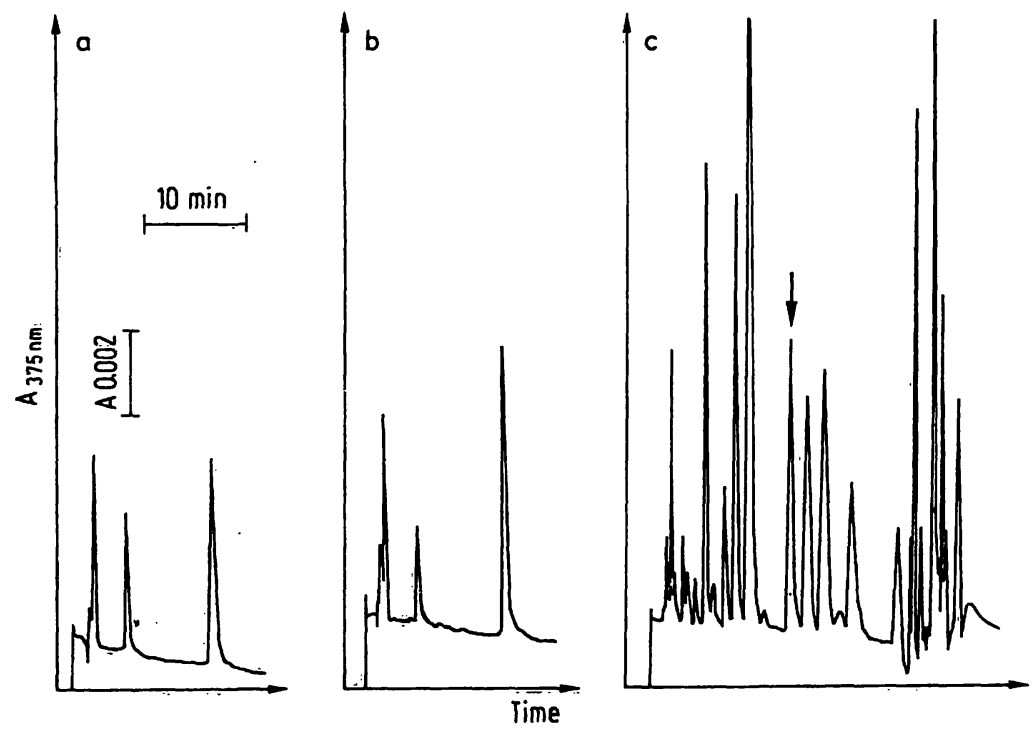

Fig. 1. Typical high performance liquid chromatograms obtained from carboxymethylcysteine, cysteine and human plasma. a: Carboxymethylcysteine $(57.8 \mu \mathrm{mol} / 1,0.25 \mathrm{ml})$ was added to $100 \mathrm{~g} / \mathrm{l} \mathrm{Na}{ }_{2} \mathrm{CO}_{3}(0.1 \mathrm{ml})$, water $(0.25 \mathrm{ml})$ and 2,4-dinitrofluorobenzene $(10 \mu \mathrm{l})$, followed by incubation at $30^{\circ} \mathrm{C}$ for $1 \mathrm{~h}$ with vigorous shaking. The reaction mixture was treated in the same manner as described for HPLC. A $10 \mu \mathrm{l}$ aliquot of the aqueous phase was injected into the chromatograph.

b: Cysteine $(82.5 \mu \mathrm{mol} / 1,0.25 \mathrm{ml})$ was added to $100 \mathrm{~g} / 1 \mathrm{Na}_{2} \mathrm{CO}_{3}(0.1 \mathrm{ml})$, water $(0.2 \mathrm{ml})$ and $0.5 \mathrm{~mol} /$ iodoacetic acid $(50 \mu \mathrm{l})$, followed by incubation at room temperature for $20 \mathrm{~min}$. After derivatization with 2,4-dinitrofluorobenzene as described for HPLC, a $10 \mu \mathrm{l}$ aliquot of the aqueous phase was subjected to high performance liquid chromatography.

-c: Human plasma was treated in the procedure for total cysteine determination as described for HPLC. A $10 \mu$ l aliquot was subjected to high performance liquid chromatography. 


\section{Conditions for colour development}

A methanolic solution of cysteine was used for the establishment of reaction conditions.

a) Time course and effect of reaction temperature

As shown in figure 3 , it took about $2 \mathrm{~h}$ at $60^{\circ} \mathrm{C}$ to develop the maximum absorbance. At $25^{\circ} \mathrm{C}$, even after $5 \mathrm{~h}$, the absorbance reached no more than $30 \%$ of the maximum absorbance attained at $60^{\circ} \mathrm{C}$. This colour was stable for at least $5 \mathrm{~h}$ at $60^{\circ} \mathrm{C}$.

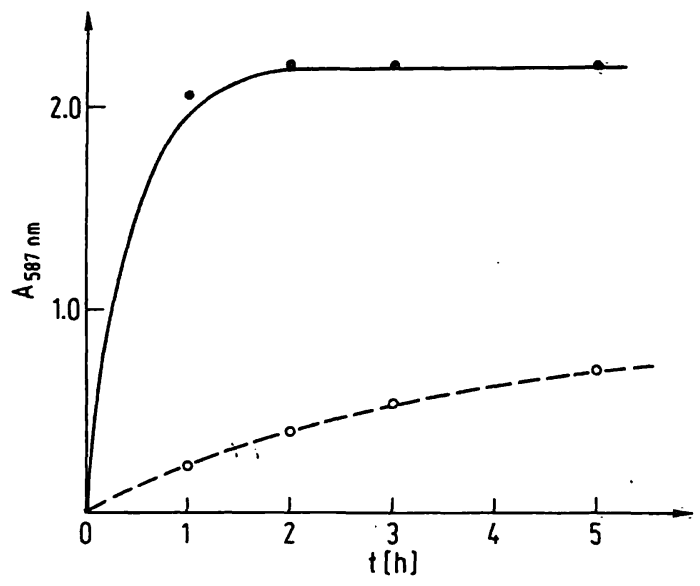

Fig. 3. Effect of the reaction time and temperature on colour development. Colour was developed at $60^{\circ} \mathrm{C}(\mathbf{O}-\mathbf{O})$ and $25^{\circ} \mathrm{C}(\mathrm{O}-\ldots-\mathrm{O})$ using cysteine $(82.5 \mathrm{nmol})$ with $1.5 \mathrm{~g} / \mathrm{l} \mathrm{p}$-dimethylaminocinnamaldehyde and $1 \mathrm{~g} / \mathrm{l} \mathrm{sulph}$ uric acid.

b) Effect of the concentration of sulphuric acid and p-dimethylaminocinnamaldehyde

Cysteine $(82.5 \mathrm{nmol})$ was reacted at $60^{\circ} \mathrm{C}$ for $2 \mathrm{~h}$ with varying concentrations of sulphuric acid and a fixed concentration of $p$-dimethylaminocinnamaldehyde $(1.5 \mathrm{~g} / \mathrm{l})$. As shown in figure $4 \mathrm{a}$, the maximum absorbance was observed in the range from 0.8 to $1 \mathrm{~g} / 1$ sulphuric acid.

Cysteine $(41.3 \mathrm{nmol})$ was reacted at $60^{\circ} \mathrm{C}$ for $2 \mathrm{~h}$ with varying amounts of $p$-dimethylaminocinnamaldehyde and a fixed concentration of sulphuric acid $(1 \mathrm{~g} / \mathrm{l})$. Figure $4 \mathrm{~b}$ shows that the optimal concentration of $p$-dimethylaminocinnamaldehyde is $1.5 \mathrm{~g} / 1$.

c) Effect of different acids on colour development

Sulphuric acid, phosphoric acid and p-toluenesulphonic acid were tested as acid catalysts in the colour reaction. $p$-Toluenesulphonic acid gave almost the same results as sulphuric acid, and the optimal concentration was $2 \mathrm{~g} / \mathrm{l}$. However, phosphoric acid gave half the absorbance obtained in the presence of sulphuric acid or $p$-toluenesulphonic acid.

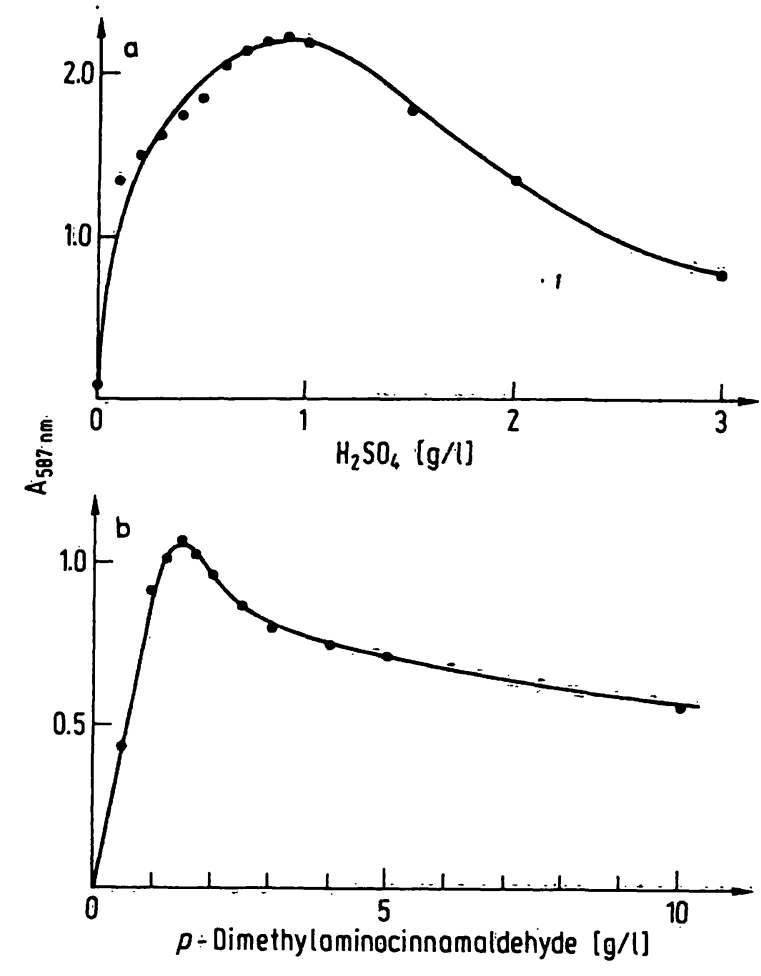

Fig. 4. Effect of the concentrations of sulphuric acid and p-dimethylaminocinnamaldehyde on colour development. In figure $4 \mathrm{a}$, cysteine $(82.5 \mathrm{nmol})$ was reacted at $60^{\circ} \mathrm{C}$ for $2 \mathrm{~h}$ with $p$-dimethylaminocinnamaldehyde $(1.5 \mathrm{~g} / \mathrm{l})$ and sulphuric acid from 0 to $2 \mathrm{~g} /$.

In figure $4 \mathrm{~b}$, cysteine $(41.3 \mathrm{nmol})$ was reacted with $p$ dimethylaminocinnamaldehyde from 0 to $10 \mathrm{~g} / \mathrm{l}$ and sulphuric acid (1 g/l).

\section{d) Effect of water on colour development}

The colour was developed under standard conditions $(1.5 \mathrm{~g} / \mathrm{l} \quad p$-dimethylaminocinnamaldehyde, $1 \mathrm{~g} / 1$ sulphuric acid, at $60^{\circ} \mathrm{C}$ for $2 \mathrm{~h}$ ), except that varying amounts of water were added to the reaction mixture. As shown in figure 5, the presence of water significantly inhibits colour development.

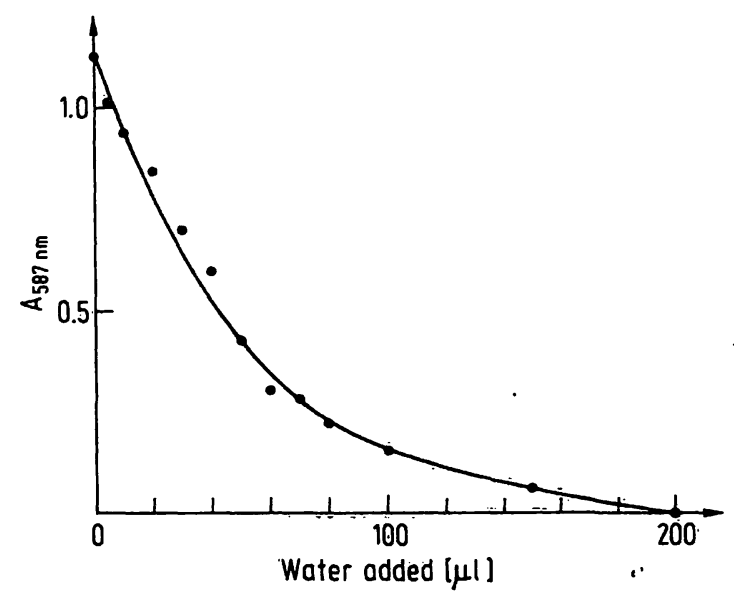

Fig. 5. Effect of water on colour development. Cysteine $(41.3 \mathrm{nmol})$ was reacted at $60^{\circ} \mathrm{C}$ for $2 \mathrm{~h}$ with $p$-dimethylaminocinnamaldehyde $(1.5 \mathrm{~g} / \mathrm{l})$ and sulphuric acid $(1 \mathrm{~g} / \mathrm{l})$ in the presence of water from 0 to $200 \mu \mathrm{l}$ with a total volume of $2.0 \mathrm{ml}$.

$$
.6
$$




\section{Standard curves and sensitivity}

As shown in figure 6, the absorbance at $587 \mathrm{~nm}$ followed Beer's law in the range from 0.825 to 413 $\mu \mathrm{mol} / \mathrm{l}$. The apparent molar lineic absorbance at $587 \mathrm{~nm}$ was calculated to be $5000 \mathrm{~m}^{2} \cdot \mathrm{mol}^{-1}$. Good reproducibility was also observed (coefficient of variation $1.29 \%(n=5))$ when cysteine $(41.3 \mathrm{nmol})$

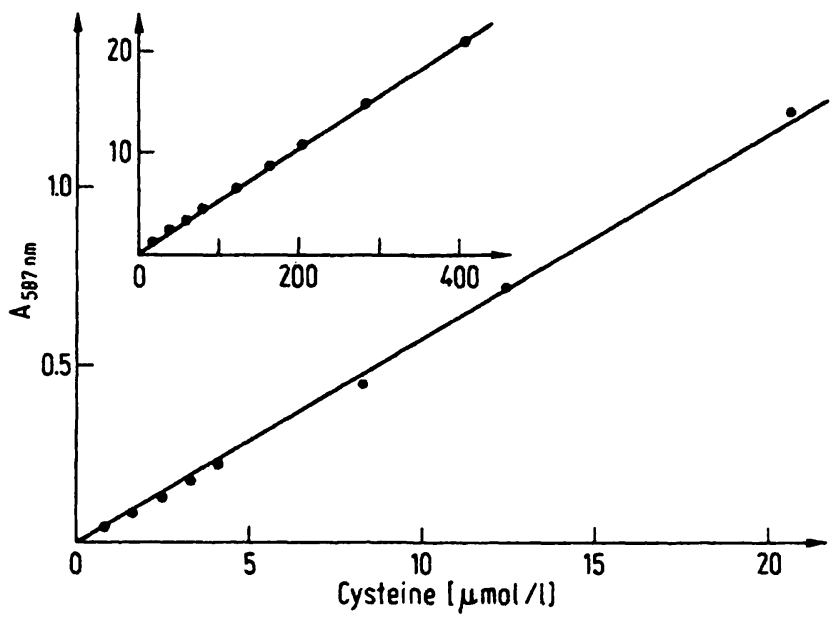

Fig. 6. Standard curves of cysteine. Varying amounts of cysteine (methanolic solution) from 0.825 to $413 \mu \mathrm{mol} / \mathrm{l}$ was reacted at $60^{\circ} \mathrm{C}$ for $2 \mathrm{~h}$ with $p$-dimethylaminocinnamaldehyde $(1.5 \mathrm{~g} / \mathrm{l})$ and sulphuric acid $(1 \mathrm{~g} / \mathrm{l})$. Dithiothreitol $(0.25 \mathrm{~g} / 1)$ was present in the mixture containing cysteine below $4.13 \mu \mathrm{mol}$.

was treated by the procedure for cysteine in aqueous solution. And coefficients of daily variation $(n=5)$ were $3.76 \%, 4.31 \%$ and $6.63 \%$, when cysteine $(8.25,41.3$ and $82.5 \mathrm{nmol}$, respectively) was treated by this procedure.

\section{Specificity of the colour reaction}

Specificity of the colour reaction was studied using different amino acids, peptides, SH compounds and several components in urine.

The following compounds did not give a colour around $587 \mathrm{~nm}$ : Asp, Asn, Glu, Gln, Thr, Ser, Met, Pro, Hyp, Gly, Ala, Val, Ile, Leu, Tyr, Phe, Trp, Lys, Arg, cystine, cystamine, cystathionine, GSH, GSSG, homocystine, homocysteine, 2-mercaptoethanol, $\mathrm{N}$ acetylcysteine, S-methylcysteine, cysteic acid, taurine, urea, uric acid and creatine.

Only cysteamine and cysteine methyl ester showed the positive colour reaction. The coloured solution obtained from cysteamine exhibited absorption maxima at 482 and $562 \mathrm{~nm}$. The apparent molar lineic absorbance at $562 \mathrm{~nm}$ was $2500 \mathrm{~m}^{2} \cdot \mathrm{mol}^{-1}$, half the value of cysteine.

\section{Cysteine in amino acid mixtures}

Cysteine $(41.3 \mathrm{nmol})$ was added to the amino acidmixtures containing 20 common amino acids in equimolar amounts (sample I) and 5-fold molar amounts (sample II), and cysteine was determined in the procedure described for cysteine in aqueous solution. The resulting values for cysteine were $39.4 \mathrm{nmol}$ in the sample I, and $34.8 \mathrm{nmol}$ in the sample II.

Individual determination of cysteine and cystine in an aqueous solution

Aqueous solutions $(0.5 \mathrm{ml})$ containing varying amounts of cysteine, both cysteine and cystine, and cystine were prepared, and analysed for cysteine and total cysteine after reduction with dithiothreitol as described in "Methods". The results are summarized in table 1 , indicating that the addition of dithiothreitol under acidic conditions almost completely protects the oxidation of cysteine to cystine through the analytical process, and dithiothreitol almost completely reduces cystine to cysteine under alkaline conditions.

Tab. 1. Individual determination of cysteine and cystine in an aqueous solution.

\begin{tabular}{|c|c|c|c|}
\hline $\begin{array}{l}\text { Cysteine } \\
\text { added }(\mu \mathrm{g})\end{array}$ & $\begin{array}{l}\text { Cystine } \\
\text { added }(\mu \mathrm{g})\end{array}$ & $\begin{array}{l}\text { Cystein } \\
\text { without } \\
\text { reductic }\end{array}$ & $\begin{array}{l}\text { nined }(\mu \mathrm{g}) \\
\text { with reduction }\end{array}$ \\
\hline 2.5 & 0 & 2.47 & 2.91 \\
\hline 5 & 0 & 4.86 & 5.67 \\
\hline 10 & 0 & 10.4 & 11.8 \\
\hline 2.5 & 2.5 & 2.37 & 5.35 \\
\hline 5 & 5 & 4.90 & 11.9 \\
\hline 10 & 10 & 10.7 & 22.2 \\
\hline 0 & 2.5 & 0.03 & 2.40 \\
\hline 0 & 5 & 0.06 & 4.81 \\
\hline 0 & 10 & 0.12 & 10.1 \\
\hline
\end{tabular}

All values were determined from a standard curve of a methanolic solution of cysteine.

\section{Recovery test}

With the aim of applying this procedure to biological samples, recovery tests were carried out. Various amounts of cysteine or cystine were added to human plasma, and they were measured by the respective procedure under "Methods". The results are summarized in table 2. Recoveries of cysteine and cystine were 98.5 to $102.9(100.7 \pm 2.2)$, and 94.2 to $102.2(99.0 \pm 3.8)$ per cent, respectively. 
Tab. 2. Recoveries of cysteine and cystine added to human plasma

\begin{tabular}{|c|c|c|c|c|c|}
\hline $\begin{array}{l}\text { Cysteine } \\
\text { added } \\
(\mathrm{nmol} / 0.4 \mathrm{ml})\end{array}$ & $\begin{array}{l}\text { Cystine } \\
\text { added } \\
(\mathrm{nmol} / 0.4 \mathrm{ml})\end{array}$ & $\begin{array}{l}\text { Cysteine } \\
\text { found } \\
(\mathrm{nmol} / 0.4 \mathrm{ml})\end{array}$ & $\begin{array}{l}\text { Total cysteine } \\
\text { found } \\
(\mathrm{nmol} / 0.4 \mathrm{ml})\end{array}$ & $\begin{array}{l}\text { Recovery } \\
\%\end{array}$ & Mean $\pm S D$ \\
\hline 0 & - & 2.3 & - & & $\therefore$, $100.7 \pm 2.2$ \\
\hline 20.6 & - & 22.6 & - & 98.5 & \\
\hline 41.3 & - & 43.9 & - & 100.7 & \\
\hline 82.5 & - & 87.2 & - & 102.9 & \\
\hline - & 0 & - & 23.8 & & $99.0 \pm 3.8$ \\
\hline - & 10.4 & - & 33.6 & 94.2 & \\
\hline- & 20.8 & - & 44.1 & 97.6 & \\
\hline- & 41.6 & - & 66.3 & 102.2 & \\
\hline - & 62.4 & - & 87.4 & 101.9 & \\
\hline
\end{tabular}

Varying amounts of cysteine and cystine were added to human plasma sample after deproteinization, and cysteine and total cysteine were measured by the respective procedures, for cysteine in plasma and cysteine and total cysteine in plasma, under Methods.

Each value is the mean from duplicate determinations.

Comparison of results obtained by the present method, the method of Gaitonde and high performance liquid chromatography

In order to evaluate the analytical values obtained by the present method, cysteine, cystine and total cysteine were determined by the method of Gaitonde and by a high performance liquid chromatographic method devised by us. Table 3 shows that the values obtained by the present method are in good agreement with those obtained by the other methods.

Tab. 3. Cysteine, cystine and total cysteine concentration in human plasma determined by the present method, the method of Gaitonde and the high performance liquid chromatographic method.

\begin{tabular}{lcll}
\hline & $\begin{array}{l}\text { Present } \\
\text { method }\end{array}$ & $\begin{array}{l}\text { Method of } \\
\text { Gaitonde }\end{array}$ & $\begin{array}{l}\text { High } \\
\text { performance } \\
\text { liquid chro- } \\
\text { matography }\end{array}$ \\
\hline Cysteine & $\left.5.86^{*}\right)$ & 4.95 & 4.29 \\
& $\left.3.71^{* *}\right)$ & & \\
Cystine & $\left.42.9^{* *}\right)$ & 45.8 & 40.0 \\
Total cysteine & $\left.90.0^{* *}\right)$ & 96.6 & 84.2 \\
\hline
\end{tabular}

$\left.{ }^{*}\right)$ Method for cysteine in plasma.

**) Method for cystine and total cysteine in plasma.

Each value is the mean from duplicate determinations, and presented as $\mu \mathrm{mol} / \mathrm{l}$.
Chromogen from the reaction of cysteine with $p$ dimethylaminocinnamaldehyde

The chromogen migrated as a purple spot with an $\mathbf{R}_{\mathbf{f}}$-value of 0.55 on thin layer chromatograms (silica gel, $n$-butanol:acetic acid:water, $4+1+1$, by volume).

In order to isolate the chromogen, $L$-cysteine (60 mg), p-dimethylaminocinnamaldehyde $(175 \mathrm{mg})$ and three drops of $98 \%$ sulphuric acid were added to $15 \mathrm{ml}$ methanol, which was allowed to stand at $30^{\circ} \mathrm{C}$ for $24 \mathrm{~h}$. The reaction mixture was applied to a silica gel column $(200 \mathrm{mesh}, 42 \times 3 \mathrm{~cm})$, which was prepared with $n$-propanol. The column was washed with $n$-propanol and eluted with the mixture of $n$-butanol, acetic acid and water $(4+1+1$, by volume). The fractions of the eluate were checked by thin layer chromatography, and those with a purple spot of an $\mathbf{R}_{\mathrm{f}}$-value 0.55 were combined and evaporated under reduced pressure with a rotatory evaporator. The residue thus obtained was purple, amorphous, and soluble in methanol and water but insoluble in chloroform. The colour changed from purple to orange on addition of sodium hydroxide solution, and was not restored by acidification. The chromogen was stable in the reaction mixture, but unstable during purification. This substance appears to have a molecular weight of 390 by mass spectrometry. 


\section{Discussion}

Many methods for the determination of cysteine and cystine have been reported. By determining only cysteine or cystine, most of these are impractical. In general, cyst(e)ine is an amino acid which has proved difficult to measure. The method of Gaitonde (5) has been widely used for the determination of cysteine in perchloric acid extracts of brain, liver and blood. The method uses an acid ninhydrin reagent and is highly specific for cysteine. The present method is also utilized for the determination of cysteine and cystine, because the colour reaction is highly specific for cysteine and very sensitive.

Cysteine in biological samples is oxidized readily to cystine during extraction and pretreatment procedures. This is responsible for the difficulties encountered in the accurate determination of cysteine. We therefore devised the present method which uses di- thiothreitol to protect the thiol group under acidic conditions and reduces cystine to cysteine under alkaline conditions. Thus, it is possible to determine cysteine and cystine in one biological sample by the present method. We have used many reductants for cystine such as sodium borohydride, 2-mercaptoethanol, sodium hydrogen sulphide and hydrogen sulphide. However, they resulted in low colouration and accuracy.

Studies of many amino acids, thiol compounds, peptides and substances present in urine indicate that the essential requirement for colour development is the $\mathrm{HS}-\mathrm{CH}_{2}-\mathrm{CHR}-\mathrm{NH}_{2}$ group. The colour reaction may therefore be applicable to the determination or detection of cysteamine and peptides having a cysteine or cystine residue at their C-terminus, e.g., oxytocin and vasopressin.

The mechanism of the colour reaction and the structure of the chromogen are at present unknown.

\section{References}

1. Friedman, M., Noma, A. T. \& Wagner, J. R. (1979) Anal. Biochem. 98, 293-304.

2. Fauconnet, M. \& Rochemont, J. (1978) Anal. Biochem. 91, 403-409.

3. Brigham, M. P., Stein, W. H. \& Moore, S. (1960) J. Clin. Invest. $39,1633-1638$.

4. Fowler, B. \& Robins, A. J. (1972) J. Chromatogr. 72, 105111.

5. Gaitonde, M. K. (1967) Biochem. J. 104, 627-633.

6. Haux, P. \& Natelson, S. (1970) Clin. Chem. 16, 366-369.

7. Krishna, R. R., Siraj. P. \& Sastry, C. S. P. (1979) Curr. Sci. 48. 815-816.

8. Bengtsson, G. \& Odham, G. (1979) Anal. Biochem. 92, $426-433$

9. Váradi, A. \& Pongor, S. (1979) J. Chromatogr. 173, 419424.

10. Kuzel, K. (1973) Clin. Chim. Acta 48, 377-384.

11. Takahashi, H., Nara, Y., Yoshida, T., Tsujimura, K. \& Megro, H. (1981) Agricult. Biol. Chem. 45, 79-85.

12. Tanaka, H., Imahara, H., Esaki, N. \& Soda, K. (1981) Agricult. Biol. Chem. 45, 1021-1022.

13. Nakamura, H. \& Tamura, Z. (1981) Anal. Chem. 53, 21902193.

14. Reed, D. J., Babson, J. R., Beatty, P. W., Brodie, A. E., Ellis, W. W. \& Potter, D. W. (1980) Anal. Biochem. 106, 55-62.

15. Saetre, R. \& Rabenstein, D. L. (1978) Anal. Biochem. 90 , 684-692.

16. Law, J. H. \& Carter, H. E. (1957) In: Biochemical Preparations (Shemin, D., ed.), Vol. 5, pp. 93-96, John Wiley \& Sons İnc., New York.

17. Stein, H. W. \& Moore, S. (1954) J. Biol. Chem. 211. 915926.

Prof. Dr. Shinji Ohmori

Faculty of Pharmaceutical Sciences Okayama University

700 Okayama Tsushima Naka 1-1

Japan 


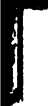

。

。

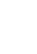

